\title{
BIOCHEMICAL PROFILE OF Calotropis procera FLOWERS
}

Malik F. H. Ferdosi ${ }^{1}$, Iqra Haider Khan ${ }^{2},{ }^{*}$ Arshad Javaid ${ }^{2}$, Muhammad Nadeem ${ }^{3}$ and Ayesha Munir ${ }^{4}$

\begin{abstract}
Calotropis procera (Aiton) W.T. Aiton is a medicinal weed of family Asclepiadaceae. This study was carried out to explore the biochemical profile of $C$. procera flowers collected from Southern Punjab region of Pakistan. Methanolic flower extract of $C$. procera was subjected to GC-MS analysis. There were 30 compounds identified in this extract. The predominant compound was $y$-sitosterol with $15.39 \%$ peak area. Other abundantly occurring compounds included stigmasterol $(9.22 \%)$, 9,12-octadecadienoic acid (Z,Z)-, methyl ester (9.01\%), campesterol $(8.63 \%)$, aamyrin acetate $(8.25 \%)$, $\beta$-amyrin $(8.09 \%)$, hexadecanoic acid, methyl ester (7.91\%), 11-octadecenoic acid, methyl ester (6.15\%), and 2-methoxy-4-vinylphenol (5.66\%). Moderately abundant compounds included nonacos-1-ene $(2.83 \%)$, methyl stearate $(1.57 \%)$, pentacosane $(1.44 \%)$, phytol $(1.33 \%)$, heptacos-1-ene $(1.20 \%)$, heneicosane $(1.19 \%)$, and 1 -hexacosene $(1.09 \%)$. The remaining less abundant compounds were present with peak areas less than $1 \%$. Literature survey showed that the major compounds identified in the flower extract of $C$. procera possess various bioactivities including ant-diabetic, anticancer, antihyperglycemic, antioxidant, antimicrobial and anti-inflammatory.
\end{abstract}

Keywords: Calotropis procera, Flowers, GC-MS analysis, Phytochemicals.

Citation: Ferdosi, M. F. H.; I. H. Khan; A. Javaid; M. Nadeem and A. Munir. 2021. Biochemical Profile of Calotropis procera Flowers. Pak. J. Weed Sci. Res., 27 (3):341349

\footnotetext{
${ }^{1}$ Department of Horticulture, Faculty of Agricultural Sciences, University of the Punjab, Quaid-i-Azam Campus, Lahore 54590, Pakistan

${ }^{2}$ Department of Plant Pathology, Faculty of Agricultural Sciences, University of the Punjab, Quaid-i-Azam Campus, Lahore 54590, Pakistan ${ }^{3}$ Department of Horticulture, University of Okara, Pakistan ${ }^{4}$ Institute of Chemistry, University of the Punjab, Quaid-i-Azam Campus, Lahore 54590, Pakistan

*Corresponding author's email: arshad.iags@pu.edu.pk, arshadjpk@yahoo.com
} 


\section{INTRODUCTION}

\begin{abstract}
Calotropis procera is a perennial medicinal shrub of family Asclepiadaceae that grows mainly in arid to semi-arid regions (Radhaboy et al., 2019). The plant is native to Middle East Asia, Latin America, Africa and Southwestern Asia (Kaur et al., 2021). It reproduces from seeds and commonly has a height of $1-2 \mathrm{~m}$. It is an erect spreading shrub that comprises of a single or few primary stems giving rise to several secondary and tertiary stems (Fig. 1). Being a drought and salt tolerant plant, it profusely grows and can survive under harsh environmental conditions (Coêlho et al., 2019). It is commonly found along watercourses, roadsides, coastal dunes, overgrazed pastures and river flats. The successful invasion of $C$. procera can be attributed to its high reproductive potential (Kaur et al., 2021).
\end{abstract}

Since ancient times, C. procera is utilized in traditional medicine systems to cure human diseases (Kumari and Sood, 2020). It contains flavonoids, tannins, cardiac glycosides, alkaloids, triterpenes and/or sterols possessing antioxidant, pharmacological, and cytostatic properties (Radwan et al., 2019; Ghramh et al., 2021). The plant also has antidiarrheal, analgesic, anti- inflammatory, antiulcer, antimicrobial and insecticidal activities (Waheed et al., 2016; Falana and Nurudeen, 2020; Kumari and Chaudhary, 2021). In Pakistan, mudarin and asclepsin compounds have been isolated from this plant with bactericidal, emetocathartic, vermicidal and digitalic properties (Taylor, 2004). Western and Central African countries utilize aerial parts of this plant to cure skin diseases, sores, sinus, diarrhea, fistula and wounds (Yaniv and Koltai, 2018). Moreover, root bark is used for treatment of fever, leprosy, snake bite, malaria, dysentery, dermatitis and elephantiasis. Plant leaves serve as an effective cure for burn injuries, rheumatism and mumps, whereas flowers are used as a tonic to treat catarrh and asthma (Mali et al., 2019). Traditionally, dry C. procera powder is given to the patients for the treatment of asthma, bronchitis, hepatic and spleen enlargement (Paul and Kumar, 2018). In addition, processed plant latex is commercially available to treat eyes, tooth aches, hair fall, paralysis, rheumatoid and intermittent fevers (Meena et al., 2011). Keeping in view ethnophormacological importance of $C$. procera, this study was carried out to identify various phytoconstituents present in flowers of this plant through GC-MS analysis.

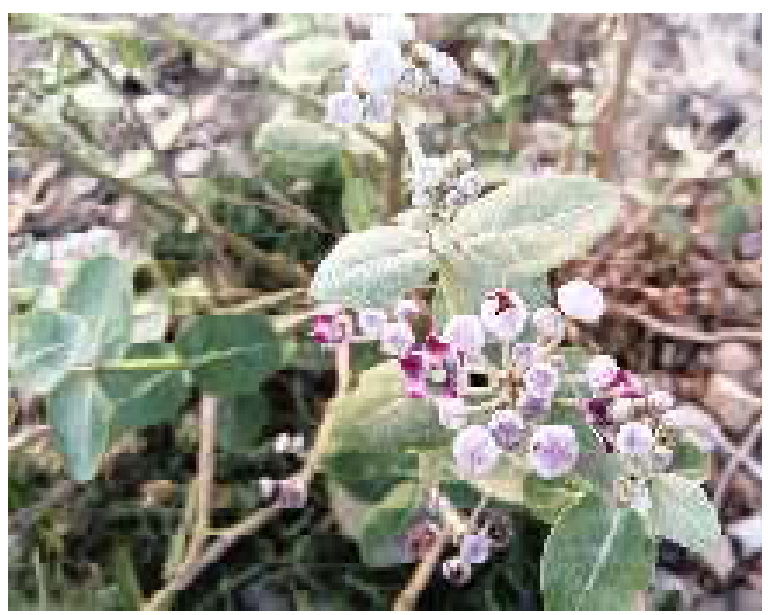

Fig. 1: Calotropis procera growing on a deserted land of Bahawalpur. 


\section{MATERIALS AND METHODS}

\section{Collection of flowers}

The fresh and healthy full bloomed flowers of $C$. procera were plucked from Bahawalpur district (Southern Punjab). These plants were growing along the roadside; nationally known as N5 under the jurisdiction of National Highways Authority. The flowers were kept in a paper bag and shifted to the laboratory. Before proceeding to further procedures, the plant specimen was identified and confirmed by a botanist Dr. Arshad Javaid (also a co-author of this article).

\section{Preparation of methanolic extract}

The flowers were dried under room temperature to evaporate the moisture. Thereafter, the flowers were also kept in the oven at a temperature of $35{ }^{\circ} \mathrm{C}$ for one day for complete moisture evaporation. The dried flowers were then ground into a fine powder form by using a pastel and mortar. This finely grounded powder $(10 \mathrm{~g})$ of the $C$. procera flowers was completely soaked in $50 \mathrm{~mL}$ of analytical grade methanol in a graduated flask for 15 days. After that, the flower extract was filtered and subjected to GC-MS examining for biochemical profiling (Ferdosi et al., 2021a).

\section{GC-MS analysis}

The gas chromatographic (GC) machine model 7890B (Agilent, USA) and mass spectroscopic machine model 5977A (Agilent, USA) were used for phytochemical profiling of methanolic flower extract of $C$. procera following the procedure described by Ferdosi et al. (2020). The column used was DB 5MS $(30 \mathrm{~m} \times 0.25 \mu \mathrm{m} \times 0.25$ $\mu \mathrm{m})$; injection volume was $1 \mu \mathrm{L}$; helium was used in a split less mode as a carrier gas. Oven ramping temperature at the start was $80^{\circ} \mathrm{C}$ and then raised $10^{\circ} \mathrm{C}$ per min up till $300^{\circ} \mathrm{C}$. Inlet temperature was $280^{\circ} \mathrm{C}$ with run time $50 \mathrm{~min}$. MS conditions were: scan range $50-500 \mathrm{~m} / \mathrm{z}$; solvent delay time $5 \mathrm{~min}$; and source temperature was $230^{\circ} \mathrm{C}$. Run time was 50 minutes. The spectra were compared with NIST library of 2017 version for the identification of chemical constituents and arranged in the ascending order of their retention times, respectively. The relative abundance of compounds was reported by using their peak areas. The ChemDraw software was used for drawing the structures of major compounds.

\section{RESULTS AND DISCUSSION}

There were 30 compounds identified in flower extract of $C$. procera as presented in Fig. 2. Details of these compounds are given in Table 1. Structures of the abundantly occurring compounds are presented in Fig. 3. The predominant and the most abundant compound in the extract was Y-sitosterol (15.39\%). Other abundantly occurring compounds included stigmasterol $(9.22 \%), 9,12-$ octadecadienoic acid $(Z, Z)-$, methyl ester $(9.01 \%)$, campesterol $(8.63 \%)$, a-amyrin acetate $(8.25 \%), \quad \beta$-amyrin $(8.09 \%)$, hexadecanoic acid, methyl ester (7.91\%), 11-octadecenoic acid, methyl ester (6.15\%), and 2methoxy-4-vinylphenol $(5.66 \%)$ with peak areas above $5 \%$. Seven compounds including nonacos-1-ene $(2.83 \%)$, methyl stearate $(1.57 \%)$, pentacosane $(1.44 \%)$, phytol $(1.33 \%)$, heptacos-1-ene $(1.20 \%)$, heneicosane $(1.19 \%)$, and 1 -hexacosene $(1.09 \%)$ were categorized as moderately abundant ones. The remaining compounds with peak areas less than $1 \%$ were ranked as the less abundant ones. These consist of docosanoic acid, methyl ester $(0.85 \%)$, stigmasta5,24(28)-dien-3-ol, (3.beta.,24Z)- 
$(0.77 \%)$, eicosanoic acid, methyl ester

$(0.73 \%)$, phenol, 2,2'-methylenebis[6-

(1,1-dimethylethyl)-4-methyl

$(0.69 \%)$, tetradecanal $(0.69 \%), 1-$

tetracosene

$(0.68 \%)$,

$9,19-$

cyclolanostan-3-ol, 24-methylene-, (3.beta.)- $(0.67 \%)$, phenol, 2methoxy- $(0.61 \%)$, benzofuran, 2,3dihydro- $(0.54 \%)$, and pentacos-1-ene $(0.50 \%)$.

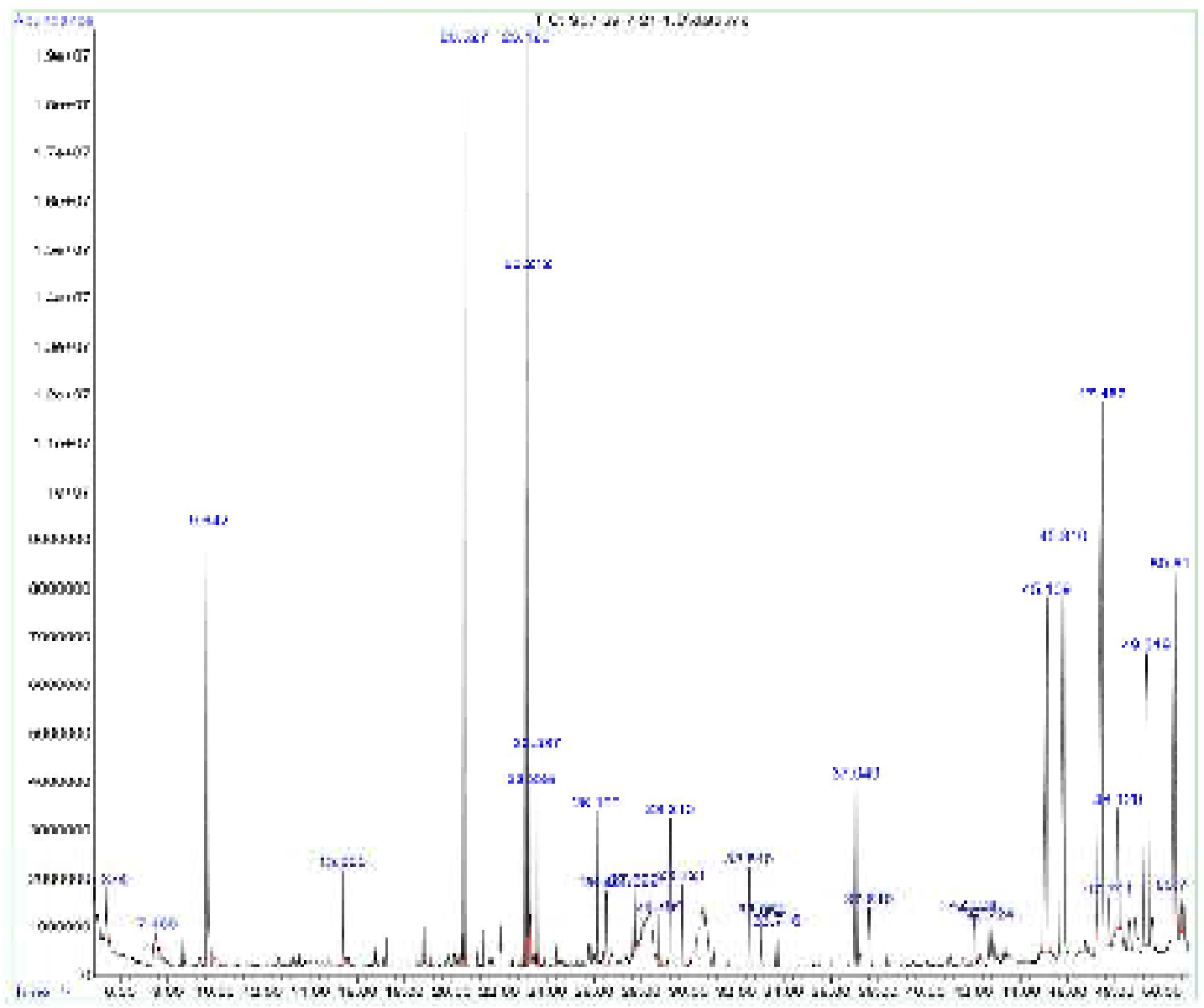

Fig. 2: Chromatogram of flower extract of Calotropis procera.

The most abundant compound Y-sitosterol (15.39\%) has been identified in many plant species including Acacia nilotica, Lippia nodiflora and Chenopodium quinoa with antidiabetic and anticancer activities (Balamurugan et al., 2011; Sundarraj et al., 2012; Khan and Javaid, 2020a). It was also found as the major compound in different species of genus Lagerstroemia with peak areas from 14.70-34.44\% showing antihyperglycemic activity (Sirikhansaeng et al., 2017).
Stigmasterol (9.22\%), an unsaturated sterol, was previously identified in a number of plant species such as Cirsium arvense flowers (Ferdosi et al., 2021b), C. quinoa leaves (Khan and Javaid, 2020), and Chenopodium murale stem (Naqvi et al., 2020). It has been shown to possess antiinflammatory and anti-diabetic (Wang et al., 2017; Zeb et al., 2017). Different derivatives of this compound namely stigmasterol glucoside, cyasterone, fucosterol epoxide, and spinasterol, fucosterol are known for 
their pharmacological properties. In addition, this important compound also has its involvement in the formation of a variety of hormones such as estrogens, androgens corticoids and progesterone (Kaur et al., 2011). 9,12-octadecadienoic acid (Z,Z)-, methyl ester $(9.01 \%)$, hexadecanoic acid, methyl ester (7.91\%), 11octadecenoic acid, methyl ester $(6.15 \%)$, docosanoic acid, methyl ester $(0.85 \%)$, eicosanoic acid, methyl ester $(0.73 \%)$ and tetracosanoic acid, methyl ester $(0.52 \%)$ belong to fatty acid methyl esters group. Such compounds are known for their antimicrobial and antioxidant activities (Ali et al., 2017; Pinto et al., 2017). $\beta$ -
Amyrin (8.09\%) has been found in various plant species including Monotheca buxifolia, Myrcianthes pungens and Melia azedarach, showing antifungal, anti-inflammatory and antioxidant activities (Jabeen et al., 2011; Okoye et al., 2014; Cardoso et al., 2020; Javed et al., 2021). aAmyrin acetate (8.25\%) showed antihyperglycaemic activity in rats (Singh et al., 2009). Campesterol $(8.63 \%)$, an anticancer compounds having a structure similar to that of cholesterol (Choi et al., 2007), reduces cholesterol absorption in the intestine by competing with cholesterol (Choudhary and Tran, 2011).

Table 1: Compounds identified in flower extract of Calotropis procera.

\begin{tabular}{|c|c|c|c|c|c|}
\hline $\begin{array}{l}\text { Sr. } \\
\text { No. }\end{array}$ & Names of compounds & $\begin{array}{l}\text { Molecular } \\
\text { formula }\end{array}$ & $\begin{array}{l}\text { Molecula } \\
\text { r weight }\end{array}$ & $\begin{array}{c}\text { Retentio } \\
\text { n } \\
\text { time } \\
\text { (min) }\end{array}$ & $\begin{array}{l}\text { Peak } \\
\text { area } \\
(\%)\end{array}$ \\
\hline 1 & Phenol, 2-methoxy- & $\mathrm{C}_{7} \mathrm{H}_{8} \mathrm{O}_{2}$ & 124.13 & 5.374 & 0.61 \\
\hline 2 & Benzofuran, 2,3-dihydro- & $\mathrm{C}_{8} \mathrm{H}_{8} \mathrm{O}$ & 120.15 & 7.460 & 0.54 \\
\hline 3 & 2-Methoxy-4-vinylphenol & $\mathrm{C}_{9} \mathrm{H}_{10} \mathrm{O}_{2}$ & 150.17 & 9.642 & 5.66 \\
\hline 4 & Tetradecanal & $\mathrm{C}_{14} \mathrm{H}_{28} \mathrm{O}$ & 212.37 & 15.365 & 0.69 \\
\hline 5 & $\begin{array}{l}\text { Hexadecanoic acid, methyl } \\
\text { ester }\end{array}$ & $\mathrm{C}_{17} \mathrm{H}_{34} \mathrm{O}_{2}$ & 270.45 & 20.527 & 7.91 \\
\hline 6 & $\begin{array}{l}\text { 9,12-Octadecadienoic acid } \\
(\mathrm{Z}, \mathrm{Z})-, \text { methyl ester }\end{array}$ & $\mathrm{C}_{19} \mathrm{H}_{34} \mathrm{O}_{2}$ & 294.47 & 23.126 & 9.01 \\
\hline 7 & $\begin{array}{l}\text { 11-Octadecenoic acid, } \\
\text { methyl ester }\end{array}$ & $\mathrm{C}_{19} \mathrm{H}_{36} \mathrm{O}_{2}$ & 296.48 & 23.212 & 6.15 \\
\hline 8 & Phytol & $\mathrm{C}_{20} \mathrm{H}_{40} \mathrm{O}$ & 296.53 & 23.335 & 1.33 \\
\hline 9 & Methyl stearate & $\mathrm{C}_{19} \mathrm{H}_{38} \mathrm{O}_{2}$ & 298.50 & 23.597 & 1.57 \\
\hline 10 & Heneicosane & $\mathrm{C}_{21} \mathrm{H}_{44}$ & 297.57 & 26.100 & 1.19 \\
\hline 11 & $\begin{array}{l}\text { Eicosanoic acid, methyl } \\
\text { ester }\end{array}$ & $\mathrm{C}_{21} \mathrm{H}_{42} \mathrm{O}_{2}$ & 326.55 & 26.490 & 0.73 \\
\hline 12 & $\begin{array}{l}\text { Phenol, 2,2'- } \\
\text { methylenebis[6-(1,1- } \\
\text { dimethylethyl)-4-methyl- }\end{array}$ & $\mathrm{C}_{23} \mathrm{H}_{32} \mathrm{O}_{2}$ & 340.49 & 27.699 & 0.69 \\
\hline 13 & Pentacos-1-ene & $\mathrm{C}_{25} \mathrm{H}_{50}$ & 350.66 & 28.764 & 0.50 \\
\hline 14 & Pentacosane & $\mathrm{C}_{25} \mathrm{H}_{52}$ & 352.68 & 29.213 & 1.44 \\
\hline 15 & $\begin{array}{l}\text { Docosanoic acid, methyl } \\
\text { ester }\end{array}$ & $\mathrm{C}_{23} \mathrm{H}_{46} \mathrm{O}_{2}$ & 354.61 & 29.721 & 0.85 \\
\hline 16 & Heptacos-1-ene & $\mathrm{C}_{27} \mathrm{H}_{54}$ & 378.71 & 32.540 & 1.20 \\
\hline 17 & Tetracosane & $\mathrm{C}_{24} \mathrm{H}_{50}$ & 338.65 & 33.064 & 0.68 \\
\hline 18 & $\begin{array}{l}\text { Tetracosanoic acid, methyl } \\
\text { ester }\end{array}$ & $\mathrm{C}_{25} \mathrm{H}_{50} \mathrm{O}_{2}$ & 382.66 & 33.716 & 0.52 \\
\hline 19 & Nonacos-1-ene & $\mathrm{C}_{29} \mathrm{H}_{52}$ & 400.72 & 37.049 & 2.83 \\
\hline 20 & 1-Hexacosene & $\mathrm{C}_{26} \mathrm{H}_{52}$ & 364.69 & 37.610 & 1.09 \\
\hline
\end{tabular}




\begin{tabular}{llcccc}
$\mathbf{2 1}$ & 1-Nonadecene & $\mathrm{C}_{19} \mathrm{H}_{38}$ & 266.50 & 42.034 & 0.85 \\
$\mathbf{2 2}$ & 1-Tetracosene & $\mathrm{C}_{24} \mathrm{H}_{48}$ & 336.63 & 42.724 & 0.68 \\
$\mathbf{2 3}$ & Campesterol & $\mathrm{C}_{28} \mathrm{H}_{48} \mathrm{O}$ & 400.68 & 45.109 & 8.63 \\
$\mathbf{2 4}$ & Stigmasterol & $\mathrm{C}_{29} \mathrm{H}_{48} \mathrm{O}$ & 412.69 & 45.810 & 9.22 \\
$\mathbf{2 5}$ & Y-Sitosterol & $\mathrm{C}_{29} \mathrm{H}_{50} \mathrm{O}$ & 414.70 & 47.452 & 15.39 \\
$\mathbf{2 6}$ & Stigmasta-5,24(28)-dien-3- & $\mathrm{C}_{29} \mathrm{H}_{48} \mathrm{O}$ & 412.69 & 47.741 & 0.77 \\
& ol, (3.beta.,24Z)- & & & \\
$\mathbf{2 7}$ & a-Amyrin & $\mathrm{C}_{30} \mathrm{H}_{50} \mathrm{O}$ & 426.71 & 48.120 & 2.26 \\
$\mathbf{2 8}$ & B-Amyrin & $\mathrm{C}_{30} \mathrm{H}_{50} \mathrm{O}$ & 426.71 & 49.319 & 8.09 \\
$\mathbf{2 9}$ & a-amyrin acetate & $\mathrm{C}_{32} \mathrm{H}_{52} \mathrm{O}_{2}$ & 468.8 & 50.517 & 8.25 \\
$\mathbf{3 0}$ & 9,19-Cyclolanostan-3-ol, & $\mathrm{C}_{31} \mathrm{H}_{52} \mathrm{O}$ & 440.74 & 50.752 & 0.67 \\
& 24-methylene-,(3.beta.)- & & & & \\
\hline
\end{tabular}

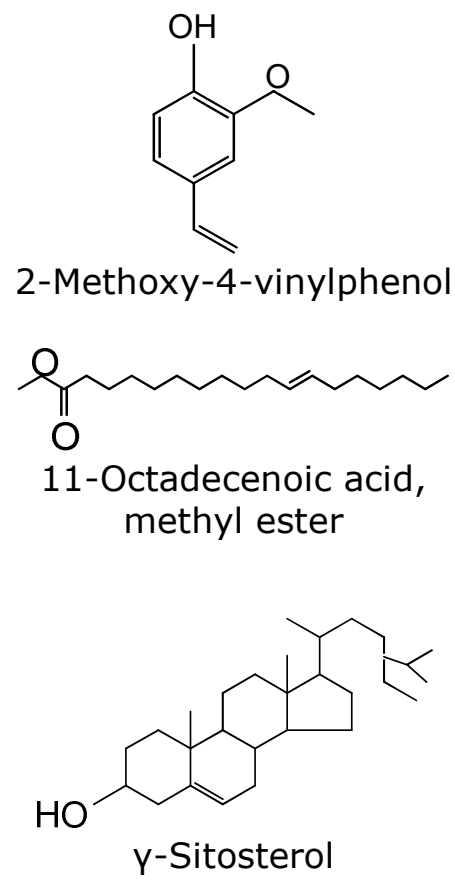

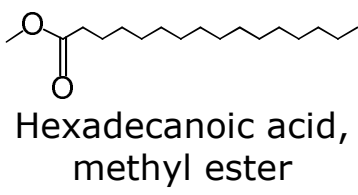
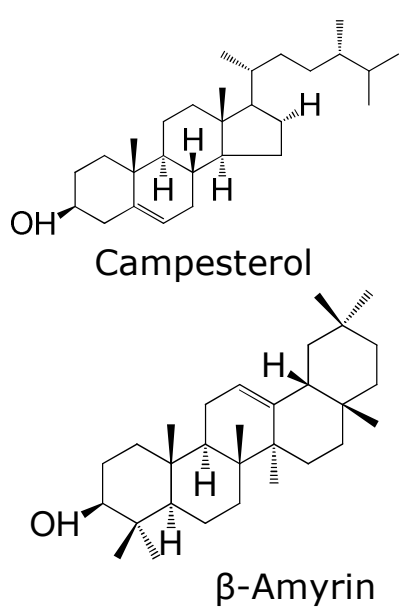

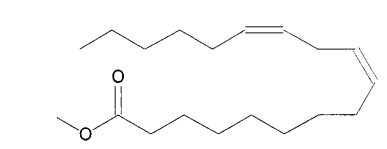

9,12-Octadecadienoic acid $(Z, Z)-$, methyl ester

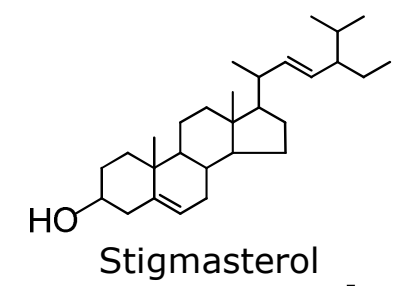

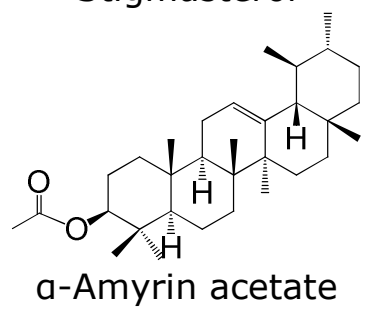

Fig. 3: Structures of major compounds in flower of Calotropis procera.

\section{Conclusion}

This study concludes that flowers of $C$. procera growing in desert land of Bahawalpur contains a number of important compounds such as $\mathrm{Y}^{-}$ sitosterol, stigmasterol, campesterol, $\beta$-amyrin, a-amyrin acetate, and different types of fatty acids methyl esters with antidiabetic, antihyperglycemic, anticancer, antimicrobial, antioxidant and/or antiinflammatory activities. 


\section{REFERENCES CITED}

Ali, A., A. Javaid and A. Shoaib. 2017. GC-MS analysis and antifungal activity of methanolic root extract of Chenopodium album against Sclerotium rolfsii. Planta Daninha 35: Article e017164713.

Balamurugan, R., V. Duraipandiyan and S. Ignacimuthu. 2011. Antidiabetic activity of $\mathrm{Y}^{-}$ sitosterol isolated from Lippia nodiflora L. in streptozotocin induced diabetic rats. Eur. J. Pharmacol. 667: 410-418.

Cardoso, B.K., H.L.M. de Oliveira, U.Z. Melo, C.M.M. Fernandez, C.F.A.A. Campo and J.E. Gonçalves, 2020. Antioxidant activity of $a$ and $\beta$ amyrin isolated from Myrcianthes pungens leaves. Nat. Prod. Res. 34: 1777-1781.

Choi, J.M., E.O. Lee, H.J. Lee, K.H. Kim, K.S. Ahn, B.S. Shim, S.H. Kim. 2007. Identification of campesterol from Chrysanthemum coronarium L. and its antiangiogenic activities. Phytother. Res., 21: 954-959.

Choudhary, S.P. and L.S. Tran. 2011. Phytosterols: Perspectives in human nutrition and clinical therapy. Curr. Med. Chem. 18 (29): 4557-4567.

Coêlho, M.R., R. Rivas, J.R.C. FerreiraNeto, V. Pandolfi, J.P. BezerraNeto, A.M. Benko-Iseppon and M.G. Santos. 2019. Reference genes selection for Calotropis procera under different salt stress conditions. PloS One 14 (4): Article e0215729.

Falana, M.B. and Q.O. Nurudeen. 2020. Evaluation of phytochemical constituents and in vitro antimicrobial activities of leaves extracts of Calotropis procera against certain human pathogens. Not. Sci. Biol. 12(2): 208-221.

Ferdosi, M.F.H., I.H. Khan, A. Javaid, T. Sattar and A. Munir. 2020. Identification of antimicrobial constituents in essential oil from Paulownia fortunei flowers Mycopath 18(2): 53-57.

Ferdosi, M.F.H., I.H. Khan, A. Javaid and M.F.A. Fardosi. 2021a. Bioactive components in methanolic flower extract of Ageratum conyzoides. Pak. J. Weed Sci. Res. 27 (2): 181-190.

Ferdosi, M.F.H., I.H. Khan, A. Javaid, M.F.A. Fardosi 2021b. GC-MS examination of methanolic extract of Cirsium arvense flower. Pak. J. Weed Sci. Res. 27(2): 173-180.

Ghramh, H.A., E.H. Ibrahim and Z. Ahmad. 2021. Antimicrobial, immunomodulatory and cytotoxic activities of green synthesized nanoparticles from Acacia honey and Calotropis procera. Saudi J. Biol. Sci. 28(6): 3367-3373.

Jabeen, K., A. Javaid, E. Ahmad and M. Athar. 2011. Antifungal compounds from Melia azedarach leaves for management of Ascochyta rabiei - the cause of chickpea blight. Nat. Prod. Res. 25(3): 264-276.

Javed, S., Z. Mahmood, K.M. Khan, S.D. Sarker, A. Javaid, I.H. Khan and A. Shoaib. 2021. Lupeol acetate as a potent antifungal compound against opportunistic human and phytopathogenic mold Macrophomina phaseolina. Sci. Rep. 11: 8417.

Kaur, N., J. Chaudhary, A. Jain and L. Kishore. 2011. Stigmasterol: a comprehensive review. Int. J. Pharmaceut. Sci. Res. 2: 22592265.

Kaur, A., D.R. Batish, S. Kaur and B.S. Chauhan. 2021. An overview of the characteristics and potential of Calotropis procera from botanical, ecological, and economic perspectives. Front. Plant Sci. 12: Article 1188.

Khan, I.H. and A. Javaid. 2020a. Comparative antifungal potential of stem extracts of four quinoa varieties against Macrophomina 
phaseolina. Int. J. Agric. Biol. 24(3): 441-446.

Khan, I.H. and A. Javaid. 2020b. Antifungal activity and GC-MS analysis of $n$-butanol extract of quinoa leaves. Bangladesh J. Bot. 49(4): 1045-1051.

Kumari, A. and N. Sood. 2020. A comparative study of traditional knowledge of Calotropis procera and Calotropis gigantea among four villages of Jaipur district of Rajasthan. J. Med. Plant Stud. 8(6): 16-20.

Kumari, I. and G. Chaudhary. 2021. Calotropis procera (Arka): A tribal herb of utmost significance. Int. J. Res. Appl. Sci. Biotechnol. 8(3): 44-54.

Mali, R.P., P.S. Rao and R.S. Jadhav. 2019. A review on pharmacological activities of Calotropis procera. J. Drug Deliv. Ther. 9(3): 947-951.

Meena, A.K., A. Yadav and M.M. Rao. 2011. Ayurvedic uses and pharmacological activities of Calotropis procera Linn. Asian $\mathrm{J}$. Tradit. Med. 6(2): 45-53.

Naqvi, S.F., I.H. Khan and A. Javaid. 2020. Hexane soluble bioactive components of Chenopodium murale stem. Pak. J. Weed Sci. Res. 26(4): 425-432.

Okoye, N.N., D.L. Ajaghaku, H.N. Okoye, E.E. Ilodigwe, C.S. Nworu and F.B. Okoye. 2014. betaAmyrin and alpha-amyrin acetate isolated from the stem bark of Alstonia boonei display profound anti-inflammatory activity. Pharmaceut. Biol. 52: 14781486.

Paul, A. and A. Kumar. 2018. Review on pharmocological properties of Aaka (Calotropis procera). Int. J. Econ. Plants 5(3): 157-162.

Pinto, M.E.A., S.G. Araújo, M.I. Morais, N.P. Sa, C.M. Lima, C.A. Rosa and L.A.R.S. Lima. 2017. Antifungal and antioxidant activity of fatty acid methyl esters from vegetable oils. An.
Acad. Bras. Ciênc. 89: 16711681.

Radhaboy, G., M. Pugazhvadivu, P. Ganeshan and P. Ramshankar. 2019. Analysis of thermo chemical behaviour of Calotropis procera parts for their potentiality. Int. J. Ambient Energy. DOI: $10.1080 / 01430750.2019 .163030$ 9

Radwan, A.M., H.A. Alghamdi and S.K. Kenawy. 2019. Effect of Calotropis procera L. plant extract on seeds germination and the growth of microorganisms. Ann. Agric. Sci. 64(2): 183-187.

Singh, A.B., D.K. Yadav, R. Maurya, A.K. $\quad$ Srivastava. 2009. Antihyperglycaemic activity of alpha-amyrin acetate in rats and $\mathrm{db} / \mathrm{db}$ mice. Nat Prod Res. 23(9):876-82.

Sirikhansaeng, P., T. Tanee, R. Sudmoon and A. Chaveerach. 2017. Major Phytochemical as $Y^{-}$ Sitosterol Disclosing and Toxicity Testing in Lagerstroemia Species. Evid.-Based Complement. Altern. Med. 2017: Article 7209851.

Sundarraj, S., R. Thangam, V. Sreevani, K. Kaveri, P. Gunasekaran, S. Achiraman and S. Kannan. 2012. Y-Sitosterol from Acacia nilotica L. induces G2/M cell cycle arrest and apoptosis through c-Myc suppression in MCF-7 and A549 cells. J Ethnopharmacol. 141: 803-809.

Taylor, L. 2004. The healing power of rainforest herbs. Square One Publishers Inc., Garden city park, USA, pp. 535.

Waheed, N., K. Jabeen, S. Iqbal and A. Javaid. 2016. Biopesticidal activity of Calotropis procera L. against Macrophomina phaseolina. Afr. J. Trad. Complement. Altern. Med. 13(6): 163-167. 
Wang, J., M. Huang, J. Yang, X. Ma, S. Zheng, S. Deng, Y. Huang, X. Yang and P. Zhao. 2017. Antidiabetic activity of stigmasterol from soybean oil by targeting the GLUT4 glucose transporter. Food Nutr. Res. 61: Article 1364117.

Yaniv, Z. and H. Koltai. 2018. Calotropis procera, apple of sodom: ethnobotanical review and medicinal activities. Isr. J. Plant Sci. 65: 55-61.

Zeb, M.A., S.U. Khan, T. Rehman, M. Sajid and S. Seloni. 2017. Isolation and biological activity of $\beta$-sitosterol and stigmasterol from the roots of Indigofera heterantha. Pharm. Pharmacol. Int. J. 5: 204-207. 